\title{
Reliability and Validity of Turkish Version of Scale of Patient Overall Satisfaction with Primary Care Physicians (SPOSPCP)
}

\author{
Hastaların Birinci Basamak Hekimlerinden Genel Memnuniyet Ölçeği \\ (SPOSPCP) Türkçe Geçerlilik - Güvenilirlik Çalışması
}

\author{
Begüm Biçer Şahin ${ }^{1}$, Süleyman Görpelioğlu ${ }^{2}$, Hülya Yıkılkan, Derya Akbıyık², Cenk Aypak ${ }^{2}$
}

\begin{abstract}
Background: Primary health care is the first point of entrance into the health care system for individuals and families who are seeking health care and a holistic approach to their health problems. The systematic evaluations of care is a mean to improve quality of primary health care. Patient satisfaction scales are one of these evaluation methods. The aim of this study was to translate and adapt the SPOSPCP to Turkish and examine its validity and reliability. Materials and Methods: This study was conducted among 920 patients, who applied to a family health center in Ankara, Turkey in 2015. The scale was translated to Turkish by a panel of reviewers. Confirmatory factor analysis was used in the study. The validity of the scale was determined by the validity coefficient and the reliability by alpha internal consistency coefficient. Results: The Cronbach's alpha of the scale was 0.96. There was a high correlation between the scores of the scale and EUROPEP. The scale was considered to be reliable and valid. Conclusion: The Turkish version of SPOSPCP can be applied to healthy Turkish population and is a proper questionnaire to evaluate satisfaction levels of patients about the primary health care physicians.
\end{abstract}

Key words: Patient satisfaction, validity and reliability, primary health care

\section{ÖZET}

Giriş: Birincil sağlık bakımı, sağlık problemlerine holistik bir yaklaşım ve çözüm arayan kişi ve ailelerin sağlık sistemine ilk giriş noktasıdır. Bu bakımın kalitesinin arttırılmasının bir yolu sistematik bir şekilde araştııılmasıdır. Bu araştırmayı yapmanın bir yolu ise hasta memnuniyeti ölçekleridir. Bu çalışmanın amacı Scale of Patient Overall Satisfaction with Primary Care Physicians isimli ölçeğin Türkçe'ye tercüme edilmesi ve geçerlik ve güvenilirliğinin test edilmesidir. Gereç ve Yöntem: $\mathrm{Bu}$ çalışma 2015 yılında Ankara'da bir aile sağlığı merkezine başvuran 920 kişide yapılıştır. Ölçek oluşturulan bir jüri tarafından Türkçeye çevrilmiştir. Çalışmada doğrulayıcı faktör analizi kullanılmıştır. Ölçeğin geçerliliği "geçerlilik katsayısı" ve güvenilirliği de "Cronbach alfa güvenilirlik katsayısı" ile değerlendirilmiştir. Bulgular: Çalışmamızda Cronbach alfa güvenilirlik katsayısını 0,96 olarak bulduk. Geçerlilik ve güvenilirliği test edilen ölçekle benzer bir ölçek olan EUROPEP ölçeği sonuçları arasında yüksek düzeyde korelasyon saptanmıştır. Bu nedenle SPOSPCP ölçeğinin Türkçe çevirisinin geçerli ve güvenilir olduğu kabul edilmiştir. Sonuç: "Hastaların Birinci Basamak Hekimlerinde Genel Memnuniyet Ölçeği” 18-75 yaş arası Türk popülasyonunun Aile Hekimlerinden memnuniyetini değerlendirmek için uygun bir ankettir.

Anahtar kelimeler: Hasta memnuniyeti, geçerlik güvenilirlik, birincil sağlık bakımı

Received / Geliş tarihi: 24.04.2017, Accepted / Kabul tarihi: 15.07.2017

${ }^{1}$ Bulgurlu Family Health Center, Istanbul, Turkey.

${ }^{2}$ Department of Family Medicine, Dışkapı Training and Research Hospital, Health Sciences University, Ankara, Turkey.

${ }^{3}$ Aile Hekimliği Uzmanı, Doç.Dr.,Ankara, Turkey

*Address for Correspondence / Yazışma Adresi: Süleyman Görpelioğlu. Department of Family Medicine, Dışkapı Training and Research Hospital, Health Sciences University, Ankara, Turkey. E-mail: sgorpelioglu@yahoo.com

Şahin B, Görpelioğlu S, Yıkılkan H, Akbıyık D, Aypak C. Reliability and Validity of Turkish Version of Scale of Patient Overall Satisfaction with Primary Care Physicians (SPOSPCP). TJFMPC, 2017;11(3): 159-163.

DOI: $10.21763 /$ tjfmpc.336138 


\section{INTRODUCTION}

Primary health care is a holistic approach to the health of individuals and the families in a community and it aims to solve the health problems of the people and protect their health. ${ }^{1}$ The importance of primary health care is its preventive and proactive characteristic and being the initial stage in seeking health care. Therefore, it is important to improve the quality of primary health care. One of the basic components of quality improvement is the systematic evaluations of the functionality of health care. $^{2,3}$ In recent years, evaluation models, that involve the service users, namely patients, has become more important in decision making and regulation of service provision., ${ }^{3,4}$ One of the evaluation methods of the quality and efficiency of health care services is patient satisfaction questionnaires. . $^{2,3,6}$

Patient satisfaction is a measure of quality from the perspective of patients and shows to what extent the expectations of patients are met. ${ }^{7}$ Patient satisfaction is a projection of the perceived benefits, the relieved difficulties, service performance, and the socio-cultural relevancy of the provided helath care. ${ }^{8,9}$ Patient satisfaction is a complex notion, that is affected by many factors from the submission of the patient to the health care center to diagnosis, treatment and rehabilitation processes. ${ }^{10}$ The factors affecting patient satisfaction can be classified into three groups. The first group is the factors related to the service users or patients; such as age, gender, social status, education level, previous experiences, perceptions etc. ${ }^{11}$ The second group are factors related to service providers: such as physicians' attitude to the patients, doctor-patient relationship, the professional knowledge and skills of the physicians etc. ${ }^{12}$ The third group are factors related to the health care facility and the environment: such as accesibility of the facility, working hours, cleanness, lightening, presence of waiting rooms etc. $^{13}$

Satisfaction of the patient is very important, since if the patients are not satisfied, they may discontinue the treatment or apply to another health care facility. ${ }^{14}$

Patient satisfaction questionnaires are quantitative and the most commonly used method of measuring patient satisfaction. Through the questionnaires, information about many different topics can be collected. However, in order for a questionnaire to measure correctly, it should be valid and reliable. ${ }^{15}$ SPOSPCP was developed by Mohammad Reza Hojat et al. in 2011. ${ }^{16}$ The main purpose of the scale was to have a feedback from patients about thier physicians in order to improve the quality of primary health care. The scale contains
10 likert-type questions with seven points. ${ }^{16}$ There is no Turkish version of this scale yet, which could be a useful measure of patient satisfaction about primary health care physicians in Turkey. The purpose of this study is to translate and culturally adapt the SPOSPCP to Turkish and examine its validity and reliability.

\section{MATERIALS AND METHODS}

\section{Study Population}

This study was conducted among patients, who applied to a Family Health Center (FHC) in Mamak, Ankara, Turkey in January 2015. Inclusion criteria were the age 18-75 and visiting the same family physician at least twice in the last three months. In January 2015, 8317 patients visited the FHC. Out of them 1200 patients were randomly selected and among them 958 patients accepted to participate in the study. After 38 patients interrupted answering the questionnaire, the study was carried out with 920 patients.

\section{Translation of the original scale}

In February 2015, permission of using the original scale was taken from the developer of the scale. , Beaton's procedures were followed for the translation and adaptation of the scale to Turkish:

Firstly, four academicians whose native language were Turkish and spoke high level English and have full knowledge of the terminology in the questionnaire, translated the original scale to Turkish. Two different drafts, T1 and T2 were developed. Then the two drafts were discussed and the best description of the questions were used and agreed on a new T1-2 draft. T1-2 draft was retranslated to English and BT1 and BT2 developed by two translators, whose native language were English. Those translations were compared with the original scale and agreed on BT1-2 as the last version of the English re-translation.

After that, a panel of reviewers was formed by the academicians, who were involved in the translations. All formats of the translations, namely T1, T2, T1-2, BT1, BT2, BT1-2, were evaluated in detail and the statements were rendered into a more understandable and culturally relevant format. That draft later was applied to 30 persons in a pilot study in order to determine the unclear and confusing statements. Eventually, according to the feedback and recommendations from the participants, the Turkish version of the scale was developed.

Statistical analysis

In order to determine the applicability of the Turkish version of the scale to Turkish people, validity and reliability of the scale were analyzed. SPSS package (Statistical Product and Service Solutions 15.0 for Windows; SPSS, Inc, Chicago) program was used in the analyses. The distribution of the variables were tested with visually (histogram and probability plots) and analytical methods (Kolmogorov-Smirnov / 
Shapiro-Wilk tests) and since the variables were not normally distributed, further analyses were done with Mann Whitney U test. The p values lower than 0.05 was considered to be statistically significant.

\section{Validity}

The validity of the scale was determined by the validity coefficient, which shows the association between the criteria or criteria groups that aims to measure with the scale. This coefficient takes values between -1 and +1 , and the values closer to +1 shows the greater strength to measure what the scale purport to measure. ${ }^{17}$

\section{Reliability}

We used reliability analyses in order to evaluate the consistency between the questions. We used alpha internal consistency coefficient for internal consistency. We considered the values between 0 and 0.4 as not reliable; 0.4 and 0.6 as low reliability; 0.6 and 0.8 as fairly reliable; 0.8 and 1 as highly reliable. $^{18}$

\section{RESULTS}

Among the 920 participants who completed the SPOSPCP, $503(54.7 \%)$ were women and 417 $(45.3 \%)$ were men. Eight hundred eighty eigth (96.5\%) participants, evaluated their family physician and remaining $32(3.5 \%)$ evaluated another family physician.

The average patient satisfaction score was $63.9 \pm 9.58$. The satisfaction scores of the patients, who were not registered to a family physician were significantly lower than those, who were registered $(p<0.05)$. Also, the satisfaction scores of male patients were significantly lower than the female patients $(\mathrm{p}<0.05)$.

In order to confirm the factor structure of the scale, first order confirmatory factor analysis (CFA) were applied. CFA, is used to evaluate to what extent a factorial model, which is made up of several observed variables, is consistent with the true values. The evaluated model can be identified with the outcomes of an empirical study or can be based on a specific theory. ${ }^{18}$ In CFA, several fit indices are used to assess the validity of the model. The most frequently used ones are: Chi-Square Goodness of Fit $(\chi 2)$, Root Mean Square Error of Approximation (RMSEA), Comparative Fit Index (CFI), NonNormed Fit Index (NNFI), Normed Fit Index (NFI), Goodness of Fit Index (GFI).i The observed values in the models: $\chi 2 / \mathrm{d}<3 ; \quad 0<\mathrm{RMSEA}<0.05$; $0.97 \leq \mathrm{NNFI} \leq 1 ; \quad 0.97 \leq \mathrm{CFI} \leq 1 ; \quad 0.95 \leq \mathrm{GFI} \leq 1 \quad$ and $0.95 \leq \mathrm{NFI} \leq 1$ show the excellent consistency; $4<\chi 2 / \mathrm{d}<5 ; 0,05<\mathrm{RMSEA}<0.08 ; 0.95 \leq \mathrm{NNFI} \leq 0.97$; $0.95 \leq \mathrm{CFI} \leq 0.97 ; 0.90 \leq \mathrm{GFI} \leq 0.95$ and $0.90 \leq \mathrm{NFI} \leq 0.95$ show the acceptable level consistency. ${ }^{18}$ Also, in order to determine the reliability of the scale, Cronbach alpha internal consistency coefficient was calculated. ${ }^{19,20,21}$ the scale.

CFA was used to determine the validity of

The structure of the SPOSPCP: In this part of the study, we applied CFA in order to confirm the unifactor and 10-question construct of the scale. In the first CFA, we investigated the questions that had no statistically significant $t$ values, however, all t values were found to be statistically significant. Therefore, all questions held their positions in the scale. The path diagram is given inFigure ; and the regression and $t$ values of the questions are given in Table 1. As seen in the table, regression and t values confirm the significance of the model.

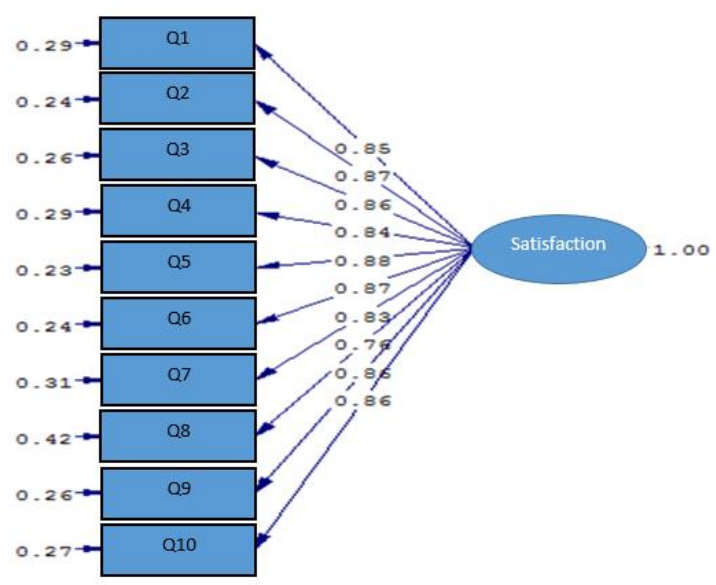

Figure 1. The path diagram of the scale

Fit indices found to be as follows: $\chi 2=367.45, \mathrm{X} 2 / \mathrm{sd}=4.32, \mathrm{RMSEA}=0.08, \mathrm{CFI}=0.95$, $\mathrm{NNFI}=0.94$ and $\mathrm{NFI}=0.95$. When we investigated the coefficients of the associations between the observed variables and their factors in the factorial construct model, we found that all coefficients were at sufficient levels. Taking the fit indices calculated with CFA into account, we agreed that the previously determined uni-factor construct of the scale was generally consistent with the collected data.

In order to determine the reliability of the scale, Cronbach alpha internal consistency coefficient was calculated (Hata! Başvuru kaynağı bulunamadı.). It was found that Cronbach alpha value for uni-dimensional scale was 0.96 and it is known that for a likert type scale, the closer the value to 1 the more reliable the scale is. Therefore, the scale can be considered to be highly reliable. ${ }^{19,20}$

The adapted SPOSPCP was applied to another 100 persons in order to determine the consistency between the pre-test and post-test scores. Due to the high correlation between pre- and 
post-test scores, the test-retest reliability was sufficient (Table ).

Concurrently, EUROPEP, a similar scale with 23 questions, was applied to 100 persons and the scores of the scale was compared with the adapted SPOSPCP. It was found that there was a high correlation between the scores of the two scales (Table ). In other words, both of the scales gave similar results.

\begin{tabular}{|l|l|l|}
\hline \multicolumn{3}{|l|}{$\begin{array}{l}\text { Table 1. Regression and } \mathbf{t} \text { values of the } \\
\text { questions in the scale }\end{array}$} \\
\hline Questions & $\begin{array}{l}\text { Regression } \\
\text { values }\end{array}$ & $\begin{array}{l}\mathrm{t} \\
\text { values }\end{array}$ \\
\hline Q1 & 0,85 & 31,65 \\
\hline Q2 & 0,87 & 33,12 \\
\hline Q3 & 0,86 & 32,40 \\
\hline Q4 & 0,84 & 31,56 \\
\hline Q5 & 0,88 & 33,70 \\
\hline Q6 & 0,87 & 33,13 \\
\hline Q7 & 0,83 & 30,83 \\
\hline Q8 & 0,76 & 26,97 \\
\hline Q9 & 0,86 & 32,64 \\
\hline Q10 & 0,86 & 32,32 \\
\hline
\end{tabular}

Table 2. Cronbach alpha values of the questions in the scale

\begin{tabular}{|l|l|l|}
\hline & $\begin{array}{l}\text { Corrected Item-Total } \\
\text { Correlation }\end{array}$ & $\begin{array}{l}\text { Cronbach's Alpha } \\
\text { if Item Deleted }\end{array}$ \\
\hline Q1 & 0,818 & 0,958 \\
\hline Q2 & 0,846 & 0,956 \\
\hline Q3 & 0,834 & 0,957 \\
\hline Q4 & 0,818 & 0,958 \\
\hline Q5 & 0,859 & 0,956 \\
\hline Q6 & 0,853 & 0,956 \\
\hline Q7 & 0,819 & 0,957 \\
\hline Q8 & 0,745 & 0,961 \\
\hline Q9 & 0,853 & 0,956 \\
\hline Q10 & 0,845 & 0,956 \\
\hline
\end{tabular}

Table 3. $R$ and $p$ values for test-retest reliability

\begin{tabular}{|l|l|l|}
\hline & $\mathrm{R}$ & $\mathrm{P} *$ value \\
\hline $\begin{array}{l}\text { Pretest-posttest } \\
\text { satisfaction score }\end{array}$ & 0,753 & 0,0001 \\
\hline
\end{tabular}

*Spearman Corelation test

\begin{tabular}{|l|l|l|}
\hline \multicolumn{2}{|l|}{ Table 4. R and p values of the SPOSPCP compared to } \\
EUROPEP scale & $\mathrm{R}$ & $\mathrm{P} *$ value \\
\hline \multicolumn{4}{|c|}{ satisfaction score- } & & \\
\hline $\begin{array}{l}\text { Pre-test satisfaction score- } \\
\text { EUROPEP }\end{array}$ & 0,878 & 0,0001 \\
\hline $\begin{array}{l}\text { Post-test } \\
\text { EUROPEP }\end{array}$ & 0,706 & 0,0001 \\
\hline
\end{tabular}

*Spearman Corelation test

\section{DISCUSSION}

This study was conducted to translate and cultural adaptat SPOSPCP to Turkish and to examine the validity and reliability of the scale. This study demonstrated acceptable levels of reliability and validity for Turkish-speaking individuals in the evaluation of patient satisfaction levels in primary health care physicians.

The validity and reliability of Turkish version of EUROPEP scale was done by Aktürk et al. and it was found that the whole scale and the subscales, such as clinical behaviors and service organization, had acceptable levels of validity and reliability. ${ }^{21}$ The scale was applied across Europe and Cronbach alpha value was found to be 0.96 for clinical behaviors and 0.87 for service organization, which are similar to the results of our study. ${ }^{21}$

An ICC value >0.75 suggest satisfactory internal consistency and test-retest reliability, respectively. ${ }^{22}$ In our study it was 0.753 , however some studies suggest 0.850 for this value. ${ }^{23}$ However, this value may be due to the likelihood of a 7-point likert scale being used in the original. While it is easier to distinguish between 4 and 5 scores on 5-point likert scales, this distinction in 7point likert may not be easy at this point. For this reason, the participant, who gives a high in the first survey may give relatively low in the second, which may reduce the correlation. Beside, the memory factor can also affect the end result.

One of the limitations of our study is, that there is no adapted version of the original scale developed by Mohammad Reza Hojat in other countries. However, due to the small number of 
questions in the questionnaire, the chance of applicability is higher compared to similar scales. In conclusion, in this study we demonstrated, that the questions in the SPOSPCP can be applied to healthy Turkish population and it is a proper questionnaire to evaluate satisfaction levels of patients aged 18-75 in primary health care physicians.

\section{REFERENCES}

1. Bilgel N, Tunç E. Aile hekimliği: tanımı, tarihçesi, amacı, önemi. Bilgel N. Aile Hekimliği. 1st ed. Bursa, Turkey: Medikal Tıp Kitabevi; 2006. pp. 1-6.

2. Vedsted P, Sokolowski I, Heje HN. Data quality and confirmatory factor analysis of the Danish EUROPEP questionnaire on patient evaluation of general practice. Scandinavian journal of primary health care. 2008;26(3):174-80.

3. Edirne T, Avc1 DK, Atmaca B. Van İlinde birinci basamakta hasta memnuniyeti: Ankete dayalı kesitsel çalışma. Türkiye Aile Hekimliğgi dergisi 2009;13(3):137-147.

4. Ersoy K, Kavucubağı G. Sağlık Kurumlarında Kalite Yönetimi, 1. Ulusal Sağlık Kuruluşları ve Hastane Yönetimi Sempozyumu, 4-7 May 1994; İzmir, Turkey: Dokuz Eylül University; 1994. pp. 349-353.

5. Kidak LB, Aksaraylı B. Yatan hasta memnuniyetinin değerlendirilmesi ve izlenmesi: eğitim ve araştırma hastanesi uygulamas1. Dokuz Eylül Üniversitesi Sosyal Bilimler Enstitüsü Dergisi 2008; 10:(3):87-119.

6. Emhan A, Bez Y, Dülek Ö. The satisfaction levels of the patients admitted to a university hospital. Dicle Medical Journal. 2010;37(3):241-247.

7. Paycı S, Ünlüoğlu İ. Dünyada ve Türkiye' de Aile Hekimliği Uygulamaları,TC Sağlık Bakanlığı, Aile Doktorları İçin Kurs Notları, 1st ed. Ankara, Turkey: 2004. pp. 23- 30.

8. Roberts JS, Coale JG, Redman RR. A history of the Joint Commission on Accreditation of Hospitals. Jama. 1987;258(7):936-40.

9. Ünalan D, Öztürk A, Tolga Y, Tasdelen C, Yazlak Z, Ögüt E ve ark. Kayseri Devlet Hastanesi'nden Poliklinik Hizmeti Alan SSK Mensubu Erişkin Hastalarda Memnuniyet Durumu. Firat Sağlık Hizmetleri Dergisi. 2008;3(8):85-98.
10. Nesanır N, Dinç G. Patient satisfaction level of the patients who were hospitalized in Manisa city. TAF Prev Med Bull, 2008; 7(5):419-428.

11. Özer A, Çakıl E. Sağlık hizmetlerinde hasta memnuniyetini etkileyen faktörler. Tip Araştırma Dergisi. 2007; 5(3):140-143.

12. Kavuncubaşı Ş, Hastane ve Sağlık Kurumları Yönetimi. Siyasal kitapevi. Ankara, Turkey. 2000; pp. 291-304.

13. Proctor E, Morrow-Howell N, Albaz R, Weir C. Patient and family satisfaction with discharge plans. Medical care. 1992;30(3):262-75.

14. Lewis JR. Patient views on quality care in general practice: literature review. Social science \& medicine (1982). 1994;39(5):655-70.

15. Hojat M, Louis DZ, Maxwell K, Markham FW, Wender RC, Gonnella JS. A brief instrument to measure patients' overall satisfaction with primary care physicians. Family medicine. 2011;43(6):412-7.

16. Çakmur H. Measurement-Reliability-Validity in Research. TAF Prev Med Bull. 2012;11(3):339-44.

17. Hayran M, Hayran M. Sağlık araştırmaları için temel istatistik. Ankara, Turkey. Omega Araştırma; 2011; pp:29-31

18. Sümer, N. Yapısal eşitlik modelleri: Temel kavramlar ve örnek uygulamalar. Türk Psikoloji Yazılar1. 2000; 3(6), 49-74.

19. Cole DA. Utility of confirmatory factor analysis in test validation research. Journal of consulting and clinical psychology. 1987;55(4):584-94.

20. Sümer N. Yapısal eşitlik modelleri: Temel kavramlar ve örnek uygulamalar. Türk Psikoloji Yazılar1. 2000. 3(6), 49-74.

21. Aktürk Z, Dağdeviren N, Şahin EM, Özer C, Yaman H, Göktaş $\mathrm{O}$ et al. Hastalar hekimleri değerlendiriyor: Europep Ölçeği. Dokuz Eylül Üniversitesi Tıp Fakültesi Dergisi, 2002; 3(16):153-160.

22. Lin, CY. Psychometric properties and gender invariance of the Chinese version of the self report pediatric quality of life inventory version 4.0: short form is acceptable. Quality of Life Research, 2012;21(1): 177-182.

23. Shrout PE, Fleiss JL. Intraclass correlations: uses in assessing rater reliability. Psychological bulletin, 1979;86(2): 420 . 